\title{
Pivotal vascular homeostatic role for endothelium-derived C-type natriuretic peptide (CNP)
}

\author{
Adrian J Hobbs \\ From 7th International Conference on cGMP Generators, Effectors and Therapeutic Implications \\ Trier, Germany. 19-21 June 2015
}

\section{Background}

The endothelium plays a fundamental role in maintaining vascular homeostasis by releasing factors that regulate local blood flow, systemic blood pressure, and the reactivity of leukocytes and platelets. Accordingly, endothelial dysfunction underpins many cardiovascular diseases, including hypertension, myocardial infarction and stroke. C-type natriuretic peptide (CNP) is a paracrine mediator that possesses a unique vaso- and cardioprotective pharmacodynamic profile; however, there is a paucity of information regarding a physiological role for CNP within the cardiovascular system.

\section{Methods and principal results}

Herein, we generated a novel endothelial cell-specific CNP knockout (ecCNP KO) mouse to investigate a potential vasoprotective role of endogenous CNP in vivo. Mice lacking endothelial CNP exhibited a fundamental, multi-faceted vascular dysfunction, including impaired endothelium-dependent dilatation, hypertension, increased leukocyte \& platelet reactivity, accelerated atherogenesis and aneurysm. Moreover, the aberrant vascular phenotype observed in ecCNP KO animals was more closely recapitulated in mice with global deletion of natriuretic peptide receptor (NPR)-C than animals lacking guanylate cyclase-coupled NPR-B. In accord, we designed \& developed a series of novel, small molecule NPR-C agonists, which are vasorelaxant in vitro and reduce blood pressure in vivo.

\section{Conclusion}

These data identify a mechanism explaining genome-wide association studies linking the NPR-C (Npr3) and Furin (a pro-protein convertase obligatory in the bioactivation of $\mathrm{CNP}$ ) loci with hypertension, and establish the importance of CNP-NPR-C signalling in preserving vascular homoeostasis and as a disease-modifying drug target.

This work was supported by the Wellcome Trust and UCL Business PLC.

Published: 2 September 2015

doi:10.1186/2050-6511-16-S1-A27

Cite this article as: Hobbs: Pivotal vascular homeostatic role for endothelium-derived C-type natriuretic peptide (CNP). BMC Pharmacology and Toxicology 2015 16(Suppl 1):A27.
Submit your next manuscript to BioMed Central and take full advantage of:

- Convenient online submission

- Thorough peer review

- No space constraints or color figure charges

- Immediate publication on acceptance

- Inclusion in PubMed, CAS, Scopus and Google Scholar

- Research which is freely available for redistribution 